\title{
EFFECT OF PREOPERATIVE TIROFIBAN ON POSTOPERATIVE MYOCARDIAL PERFORMANCE IN PATIENTS WITH LEFT MAIN CORONARY ARTERY DISEASE UNDERGOING CABG SURGERY
}

\author{
Murat Günday ${ }^{1}$, Özgür Çiftçi ${ }^{2}$, Tonguç Saba ${ }^{1}$, Mehmet Özülkü ${ }^{1}$, Olcay Eldem ${ }^{2}$, Sait Aşlamacı ${ }^{1}$ \\ Aim. In this study, we investigated the impact of tirofiban on ventricular performance \\ in patients who were diagnosed with acute coronary syndrome, found to have left \\ main coronary artery stenosis during coronary angiography, and administered \\ tirofiban prior to coronary artery bypass to prevent the recurrence of an acute \\ with left main coronary artery disease undergoing coronary artery bypass surgery. \\ Therefore, we recommend the preoperative administration of tirofiban as an \\ antithrombotic agent to patients who are undergoing coronary artery bypass for left \\ main coronary artery disease.
} coronary syndrome during the preoperative period.

Material and methods. The patients were divided into two groups. Group 1 included patients who were pre-diagnosed with acute coronary syndrome and administered tirofiban infusion in another hospital and subsequently sent to our center for advanced examination and treatment, where they exhibited left main coronary artery disease during coronary angiography and were submitted to surgery $(n=28)$. Group 2 included patients who arrived at our emergency service with chest pain, were pre-diagnosed with acute coronary syndrome in the cardiology clinic, exhibited left main coronary artery disease during coronary angiography, and were submitted to urgent surgery without receiving tirofiban infusion $(n=29)$. Standard and tissue Doppler echocardiography were applied to each patient in the preoperative and postoperative periods.

Results. After bypass surgery, the mean postoperative left ventricular myocardial performance index $(0.84 \pm 0.30)$ was significantly lower than the mean preoperative left ventricular myocardial performance index $(1.10 \pm 0.35)(p=0.001)$. The left lateral myocardial performance index was lower in group $1(0.76 \pm 0.31)$ than in group 2 $(0.92 \pm 0.27)\left(p=0.050^{\star}\right)$, but the ejection fraction was higher in group $1(61.46 \pm 7.74)$ than in group $2(52.87 \pm 11.64)\left(p=0.003^{\star}\right)$.

Conclusion. Preoperative administration of tirofiban improved postoperative left ventricular performance compared to pretreatment with aspirin alone in patients
Russ J Cardiol 2014, 4 (108), Engl.: 28-33

Key words: left main coronary artery disease, CABG, tirofiban, ventricular performance.

'Baskent University Faculty of Medicine, Department of Cardiovascular Surgery, Ankara; ${ }^{2}$ Baskent University Faculty of Medicine, Department of Cardiology, Ankara, Turkey.

Corresponding author. Özgür Çiftçi, MD Department of Cardiology, Baskent University Konya Application and Research Center, Hocacihan Mah. Saray Cad. No: 1 Selçuklu / Konya, Turkey. Tel: +9033225706 06, Fax: +903322570637, e-mail: drozgurciftci42@gmail.com

LIMA - Left internal mammarian artery, LAD - left anterior descending artery.

Received March 21, 2014.

Revision received April 03, 2014.

Accepted April 10, 2014

\section{ВЛИЯНИЕ ПРЕДОПЕРАЦИОННОЙ ТЕРАПИИ ТИРОФИБАНОМ НА ПОСЛЕОПЕРАЦИОННЫЕ ПОКАЗАТЕЛИ МИОКАРДА У БОЛЬНЫХ ПЕРЕНЕСШИХ ОПЕРАЦИЮ АОРТО-КОРОНАРНОГО ШУНТИРОВАНИЯ}

\begin{abstract}
Murat Günday ${ }^{1}$, Özgür Çiftçį ${ }^{2}$, Tonguç Saba ${ }^{1}$, Mehmet Özülkü $^{1}$, Olcay Eldem² ${ }^{2}$ Sait Aşlamacı ${ }^{1}$
Цель. В этой работе изучено влияние тирофибана на желудочковые показатели у больных, которым был поставлен диагноз «острый коронарный синдром» (ОКС), обнаружен стеноз левой коронарной артерии при коронарной ангиографии и введен тирофибан до операции коронарного шунтирования, чтобы не допустить повторения ОКС в предоперационном периоде.

Материал и методы. Больные были разделены на две группы. В группу 1 были включены пациенты, которым был предварительно поставлен диагноз ОКС, введен тирофибан в другой больнице; затем они были направлены в наш центр, им было проведены современное обследование и лечение, подтвержден стеноз левой коронарной артерии при коронарной ангиографии, и пациенты были отправлены на хирургическое лечение (n=28). 2 группа пациенты, доставленные в наш центр бригадами экстренной помощи, с болью в области груди; им был предварительно поставлен диагноз ОКС в

Результаты. После шунтирования, значение индекса послеоперационного миокарда левого желудочка $(0,84 \pm 0,30)$ был значительно ниже, чем значение индекса предоперационного миокарда левого желудочка $(1,10 \pm 0,35)(p=0,001)$. Показатель индекса левого латерального миокарда был ниже в группе 1 $(0,76 \pm 0,31)$, чем в группе $2(0,92 \pm 0,27)\left(p=0,050^{\star}\right)$, но фракция выброса была выше в группе $1(61,46 \pm 7,74)$, чем в группе $2(52,87 \pm 11,64)\left(p=0,003^{*}\right)$.

Вывод. Предоперационное введение тирофибана улучшает состояние послеоперационного левого желудочка, по сравнению с предварительным приемом аспирина у больных с заболеванием левой коронарной артерии, перенесших аорто-коронарное шунтирование. Поэтому, мы рекомендуем предоперационное введение тирофибана как антитромботического агента для пациентов, перенесших аортокоронарное шунтирование при заболевании левой коронарной артерии.
\end{abstract} клинике кардиологии, подтвержден стеноз левой коронарной артерии при коронарной ангиографии, и была назначена срочная операция, без получения инфузии тирофибана $(\mathrm{n}=29)$. Метод стандартной и тканевой допплерэхокардиографии был применен к каждому пациенту в предоперационном и послеоперационном периодах.

\section{Introduction}

Early surgical intervention is preferred for patients who are diagnosed with acute coronary syndrome and found to have left main coronary artery stenosis during coronary angiography. In hospitals where angiography cannot be used, anti-aggregant and anticoagulant drugs, such as clopidogrel,
Российский кардиологический журнал 2014, 4 (108), Англ.: 28-33

Ключевые слова: заболевание левой коронарной артерии, аорто-коронарное шунтирование, тирофибан, производительность желудочка.

aspirin, low molecular-weight heparin, and glycoprotein IIb/ IIIa antagonists, can be administered to patients who are diagnosed with acute coronary syndrome. The short action time of the glycoprotein IIb/IIIa inhibitor tirofiban, which facilitates its use up to four hours before surgery, is a distinct advantage over other drugs [1, 2]. Batyraliev et al. reported 
that the use of tirofiban after coronary angiography in patients with coronary syndrome with ST elevation improved the left ventricular ejection fraction compared to patients who were not administered tirofiban [3]. Tissue Doppler echocardiography in combination with echocardiography is a practical, reliable and well-defined non-invasive diagnostic method for investigating left and right ventricular systolic and diastolic function $[4,5]$. In this study, we used this method to investigate postoperative left and right ventricular performance in patients who were admitted directly to our hospital with acute coronary syndrome, diagnosed with left main coronary artery disease using coronary angiography, and submitted to urgent surgery. We compared the results of this group to those of patients who were pre-diagnosed with acute coronary syndrome and administered tirofiban infusion in another hospital and subsequently sent to our center for advanced examination and treatment, where they were diagnosed with left main coronary artery disease using coronary angiography and submitted to surgery.

\section{Materials and Methods}

Subjects and Study Design. In this study, we analyzed 57 consecutive patients between the ages of 40 and 85 years who had been diagnosed with acute coronary syndrome and exhibited left main coronary artery disease during coronary angiography. Gender differences were not considered when selecting patients. The patients were divided into two groups. Group 1 included patients who were pre-diagnosed with acute coronary syndrome and administered tirofiban infusion (the patients were given $0.4 \mu \mathrm{g} / \mathrm{kg} / \mathrm{min}$ of tirofiban for loading and were randomized to receive maintenance infusion at 0.1 $\mu \mathrm{g} / \mathrm{kg} / \mathrm{min}$ for 24 or $48 \mathrm{~h}$ ) in another hospital and sent to our center for advanced examination and treatment, where they exhibited left main coronary artery disease during coronary angiography and were submitted to surgery $(n=28)$. Group 2 included patients who came to our emergency service with chest pain, were pre-diagnosed with acute coronary syndrome in the cardiology clinic, exhibited left main coronary artery disease during coronary angiography, and were submitted to urgent surgery without receiving tirofiban infusion $(n=29)$. In addition, all patients in the study received only upstream aspirin treatment.

The exclusion criteria excluded patients who were in a state of cardiogenic shock, who were classified as Killip class 3 or 4 , who used clopidogrel preoperatively, who were undergoing repeat coronary artery bypass surgery, who had incomplete revascularization, who underwent off-pump coronary bypass surgery, who developed mechanical complications of coronary artery disease (e.g., post- myocard infarction ventricular septal defect or rupture of the free ventricular wall), who underwent heart valve surgery combined with coronary artery bypass (e.g., mitral valve replacement, aortic valve replacement or tricuspid valve repair), and who were administered high-dose inotrope infusion and/or fitted with an intra-aortic balloon to treat poor postoperative ventricular function.
This study was approved by the Ethics Board and the Institutional Review Board (Project no: KA13/105) of Baskent University and supported by the Baskent University Research Fund. This study was conducted according to the recommendations contained in the Declaration of Helsinki on Biomedical Research Involving Human Subjects.

Surgical Procedure. Median sternotomy was applied to all patients under general anesthesia. Systemic heparinization was performed to ensure an activated clotting time of 600$800 /$ second. The cardiopulmonary bypass was done via aorta-caval cannulation. Non-pulsatile cardiopulmonary bypass was used with a roller pump and a membrane oxygenator. The patients were routinely cooled to $28-30^{\circ} \mathrm{C}$. After the installation of the cross-clamp, a crystalloid cardioplegic solution (St. Thomas II solution) was applied every 20 minutes to protect the myocardium. Topical cooling was performed using a crystalloid ice slush solution in all patients. At the same time, two surgeons routinely removed the saphenous vein from under the right knee, the radial artery from the left arm, and the left internal mammarian artery (LIMA). Using $7 / 0$ propylene, distal anastomoses were made initially to the right coronary artery or to its posterior descending branch, subsequently to the circumflex coronary arterial system, and finally to the left anterior descending artery (LAD) and the diagonal arterial system. The LIMA was preferred as a graft for the anastomoses to the LAD artery, the saphenous vein was used for the anastomoses to the right coronary artery and the diagonal arterial system, and the radial artery was preferred for the anastomoses to the circumflex artery and its branches. The proximal anastomoses were sewn onto the aorta, installing a side-clamp. Coronary endarterectomy was not applied to any of the included patients. The patients were weaned from cardiopulmonary bypass when the rectal temperature reached $37^{\circ} \mathrm{C}$.

Echocardiographic Evaluation. During the preoperative and postoperative (i.e., $4-8$ weeks after the operation) periods, standard and tissue Doppler echocardiography were applied to each patient in the lateral decubitus position, using the Acuson Sequoia C256 Echocardiography System (Acuson, Mountain View, CA, USA), The echocardiographic images were recorded in video. Using M-mode imaging, the diastolic and systolic thicknesses of the intraventricular septum, the thickness of the posterior wall, and the end-diastolic and end-systolic diameters of the left and right ventricles were measured on the parasternal long axis. The ejection fraction was calculated.

To assess right ventricular diastolic function using pulsed wave Doppler (PW) in apical 4-chamber view, the sample volume was placed over the tips of the tricuspid valve and the right ventricular inflow samples were recorded. This procedure facilitated measurements of the early diastolic flow rate (E), the late diastolic flow rate (A), the E/A ratio, and the deceleration period of the $\mathrm{E}$ wave $(\mathrm{Edz})$. The mean of three cardiac cycles was calculated for each value.

Tissue Doppler Imaging. To accurately determine myocardial speeds, the gain adjustment of the instrument was reduced 
Table 1

The demographic and baseline echocardiographic measurements of the patient and control groups

\begin{tabular}{|l|l|l|l|}
\hline & $\begin{array}{l}\text { Group1 } \\
(\mathrm{n}=28)\end{array}$ & $\begin{array}{l}\text { Group2 } \\
(\mathrm{n}=29)\end{array}$ & $p$ \\
\hline Gender (Female/male) & 21 & 24 & 0,481 \\
\hline Age (years) & $63,71 \pm 9,71$ & $66,52 \pm 9,14$ & 0,267 \\
\hline SBP (mm Hg) & $138,86 \pm 21,15$ & $142,59 \pm 19,33$ & 0,527 \\
\hline DBP (mm Hg) & $83,64 \pm 11,77$ & $87,41 \pm 9,03$ & 0,224 \\
\hline Total cholesterol (mg/dL) & $184,94 \pm 52,63$ & $181,36 \pm 41,03$ & 0,663 \\
\hline HDL (mg/dL) & $39,12 \pm 7,31$ & $42,21 \pm 11,44$ & 0,274 \\
\hline LDL (mg/dL) & $116,82 \pm 45,63$ & $108,00 \pm 39,70$ & 0,514 \\
\hline Triglyceride (mg/dL) & $160,35 \pm 62,94$ & $154,79 \pm 78,51$ & 0,795 \\
\hline Heart rate (beats/minute) & $72,59 \pm 11,92$ & $67,13 \pm 9,62$ & 0,131 \\
\hline Preoperative blood sugar (mg/dL) & $161,56 \pm 152,81$ & $124,86 \pm 51,04$ & 0,337 \\
\hline Height (cm) & $156,65 \pm 39,58$ & $165,08 \pm 7,72$ & 0,405 \\
\hline Weight (kg) & $77,39 \pm 8,35$ & $77,69 \pm 12,53$ & 0,867 \\
\hline Hypertension & 14 & 20 & 0,109 \\
\hline Preoperative ejection fraction & $59,73 \pm 9,81$ & $58,83 \pm 15,09$ & 0,797 \\
\hline
\end{tabular}

Abbreviations: SBP - systolic blood pressure, DBP - diastolic blood pressure, $\mathrm{HDL}$ - high density lipoprotein, LDL - low density lipoprotein.

Table 2

The operation data for both groups, comparison of drainage, blood and blood products

\begin{tabular}{|l|l|l|l|}
\hline & $\begin{array}{l}\text { Group1 } \\
(\mathrm{n}=28)\end{array}$ & $\begin{array}{l}\text { Group2 } \\
(\mathrm{n}=29)\end{array}$ & $p$ \\
\hline The number of distal anastomoses & $3,48 \pm 0,79$ & $3,41 \pm 0,80$ & 0,754 \\
\hline LAD & $1,00 \pm 0,00$ & $1,00 \pm 0,00$ & 0,221 \\
\hline Diagonal artery & $0,56 \pm 0,51$ & $0,63 \pm 0,49$ & 0,682 \\
\hline intermedial & $0,22 \pm 0,43$ & $0,10 \pm 0,31$ & 0271 \\
\hline Cx artery & $1,06 \pm 0,24$ & $0,93 \pm 0,62$ & 0,380 \\
\hline $\begin{array}{l}\text { RCA artery } \\
\text { Average x-clamp period (minute) }\end{array}$ & $0,67 \pm 0,59$ & $0,67 \pm 0,48$ & 1,0 \\
\hline Average CPB period (minute) & $110,00 \pm 10,08$ & $42,00 \pm 10,11$ & 0,201 \\
\hline Full Blood & $3,36 \pm 1,43$ & $4,16 \pm 1,84$ & 0,173 \\
\hline ES & $4,55 \pm 2,11$ & $2,64 \pm 1,98$ & $0,032 *$ \\
\hline FFP & $5,24 \pm 2,31$ & $4,62 \pm 2,32$ & 0,396 \\
\hline $\begin{array}{l}\text { Chest tube drainage/24 } \mathrm{h} \text {, day } \\
\text { O (ml) }\end{array}$ & $517,86 \pm 235,02$ & $562,50 \pm 278,19$ & 0,602 \\
\hline $\begin{array}{l}\text { Chest tube drainage/24 } \mathrm{h} \text {, day } \\
\text { 1 (ml) }\end{array}$ & $366,67 \pm 349,89$ & $301,09 \pm 146,45$ & 0,545 \\
\hline $\begin{array}{l}\text { Chest tube drainage/24 } \mathrm{h} \text {, day } \\
\text { 2 (ml) }\end{array}$ & $200,00 \pm 150,00$ & $210,00 \pm 135,50$ & 0,924 \\
\hline
\end{tabular}

Abbreviations: $L A D$ - left descending coronary artery, $C x$ - circumflex coronary artery, $\mathrm{RCA}$ - right descending coronary artery, X-Clamp - cross-clamp CPB - cardiopulmonary bypass, ES - erythrocyte suspension, FFP: fresh frozen plasma.

to the lowest possible value. Throughout the procedure, the Doppler velocity was maintained at $0.5 \mathrm{~m} / \mathrm{sec}$ and the sample volume interval was maintained at $5.9 \mathrm{~mm}$. Apical 4-chamber view was used to record the myocardial speeds at the tricuspid and septal annuli. The tissue Doppler sample was recorded by positioning the PW sample volume above the myocardium at the basal septum and at the right ventricular lateral tricuspid annulus. This method makes it possible to assess the longitudi- nal movements of the right ventricle and the mutual interaction of both ventricles through a single selected window.

At these regions, we measured the systolic myocardial velocity (Sm), the early (Em) and late (Am) diastolic velocities and their ratio (Em/Am), as well as the isovolumetric relaxation times (IVRZm). The mean of these values for three consecutive heart beats was calculated.

The interval from the onset to the cessation of left ventricular outflow was used to measure the left ventricular ejection time (LVET). The interval from the onset to the end of right ventricular outflow was used to measure the right ventricular ejection time (RVET). The interval from the cessation of mitral inflow to the onset of left ventricular outflow was used to measure the isovolumetric contraction time of the left ventricle (IVCTL).

The isovolumetric relaxation time of the right ventricle (IVRTR) was defined as the interval from the cessation of right ventricular outflow to the onset of tricuspid inflow. The interval from the cessation of tricuspid inflow to the onset of right ventricular outflow was used to measure the isovolumetric contraction time of the right ventricle (IVCTR). The myocardial performance index of the right ventricle was calculated using the formula (IVCTR+IVRTR) /RVET. The myocardial performance index of the left ventricle was calculated using the formula (IVCTL+ IVRTL) /LVET.

The left ventricular Sm and ejection fraction values were used to evaluate left ventricular systolic function. The right ventricular Sm was used to evaluate right ventricular contractile function. The trans-mitral and trans-tricuspid E-wave velocity, the A-wave velocity, the E/A ratio, Em, Am, the Em/Am ratio, IVRT, IVCT, ET and myocardial performance index values were used to evaluate right and left ventricular relaxation (i.e., diastolic) function. The echocardiographic evaluation was performed by a cardiologist who was not informed about the clinical data or the echocardiographic analysis.

Statistical Analyses. SPSS software (SPSS Ver. 10.0) (SPSS Inc., Chicago IL, USA) was used to perform the statistical analyses. The numeric values were expressed as the mean \pm SD. The independent samples t-test or the Mann-Whitney U test was used for continuous variables, and the Chi-square test was used for categorical variables. Continuous variables were tested for normal distribution using the Kolmogorov-Smirnov test. Values of $p<0.05$ were accepted as statistically significant. According to the power analysis, if a $20 \%$ change in a certain variable was considered clinically significant with a two-tailed $\alpha=0.05$ and a statistical power of $80 \%$, the adequate subject count was 17 . This result indicated that a sample size of 57 participants would be sufficient. With this sample size, the statistical power was 0.930 .

\section{Results}

\section{Clinical Features of the Study Group}

The preoperative demographic characteristics are presented in Table 1. No differences in gender, age, systolic blood pressure, diastolic blood pressure, total cholesterol, 
high density lipoprotein cholesterol, low density lipoprotein cholesterol, triglycerides, preoperative blood sugar, heart rate (beats/minute), height, weight, preoperative ejection fraction, or hypertension were observed between the two groups.

\section{Surgical Data}

The surgical data are presented in Table 2. A statistically significant difference in erythrocyte suspension was observed between the two groups. No significant differences in the other parameters were observed between the study groups.

Morbidity, Mortality and the Length of Stay in the Intensive Care Unit

Throughout the study period (i.e., the six months following the day of hospitalization), no mortality was encountered among the patients included in the study. No differences in atrial fibrillation, pleural effusion, acute renal failure, stroke or pulmonary infection during the length of stay in the hospital (i.e., the first seven days of the study period) were observed between the two groups ( $p>0.05)$. In addition, no differences in the length of stay in the intensive care unit or the length of stay in the hospital were observed between the two groups ( $\mathrm{p}>0.05$ ) (Table 3).

\section{Left Ventricular Relaxation Data}

No differences in the preoperative left ventricular relaxation parameters were observed between the two groups (Table 4). In the postoperative period, no differences in the mitral $\mathrm{E} / \mathrm{A}$ ratio $(\mathrm{p}=0.939)$, left ventricular $\mathrm{Em}(\mathrm{cm} / \mathrm{s})(\mathrm{p}=0.064)$, left ventricular $\mathrm{Am}(\mathrm{cm} / \mathrm{s})(\mathrm{p}=0.737)$, the left ventricular $\mathrm{Em} / \mathrm{Am}$ ratio $(\mathrm{p}=0.265)$, left ventricular IVCT $(\mathrm{ms})$ $(p=0.102)$, or left ventricular ET $(\mathrm{ms})(\mathrm{p}=0.658)$ were observed between the two groups. Tissue Doppler IVRT (ms) was greater in group 2 than in group $1\left(\mathrm{p}=0.018^{*}\right)$ (Table 5).

\section{Right Ventricular Relaxation Parameters}

No differences in the preoperative right ventricular relaxation parameters were observed between the two groups (Table 4). In the postoperative period, no differences in the right ventricular Em $(\mathrm{cm} / \mathrm{s})(\mathrm{p}=0.167)$, right ventricular $\mathrm{Am}(\mathrm{cm} / \mathrm{s})$ $(p=0.583)$, the right ventricular Em/Am ratio $(p=0.179)$, right ventricular IVRT $(\mathrm{ms})(\mathrm{p}=0.682)$, right ventricular IVCT $(\mathrm{ms})$ $(\mathrm{p}=0.593)$, or right ventricular ET $(\mathrm{ms})(\mathrm{p}=0.201)$ values were observed between the two groups (Table 6).

\section{Left and Right Ventricular Systolic Function}

No differences in the preoperative left and right ventricular systolic function parameters were observed between the two groups (Table 4). In the postoperative period, no differences in the left ventricular $\mathrm{Sm}$ were detected between the two groups $(p=0.182)$ (Table 5). Similarly, no differences in the right ventricular Sm value for the contractile function of the right ventricle were observed between the two groups $(p=0.879)$ (Table 6). Among these parameters, the left ventricular ejection $(\mathrm{cm} / \mathrm{s})$ in the postoperative period was higher in group 1 than in group $2\left(\mathrm{p}=0.003^{*}\right)$ (Table 5).

\section{Myocardial Performance Index Values for the Left and Right Ventricles}

No differences in the preoperative myocardial performance index values for the left and right ventricles were observed between the two groups (Table 4). In the postoperative period,
Table 3

Comparison of the two groups with regard to the rates of morbidity, mortality and length of stay in the ICU

\begin{tabular}{|l|l|l|l|}
\hline & Group 1 & Group 2 & $p$ \\
\hline AF & 1 & 6 & 0,161 \\
\hline Pleural effusion & 1 & 2 & 0,856 \\
\hline ARF & 1 & 0 & 0,204 \\
\hline Sternum infection & 0 & 1 & 0,431 \\
\hline Stroke & 1 & 0 & 0,204 \\
\hline Pulmonary infection & 1 & 0 & 0,204 \\
\hline Length of stay in the ICU (days) & $2,94 \pm 1,16$ & $2,59 \pm 0,97$ & 0,296 \\
\hline Length of stay in the hospital (days) & $13,17 \pm 7,37$ & $9,93 \pm 4,45$ & 0,107 \\
\hline
\end{tabular}

Abbreviations: AF - atrial fibrillation, ARF — Acute renal failure.

Table 4

Preoperative left and right ventricular systolic and diastolic function measurements

\begin{tabular}{|l|l|l|l|}
\hline & Group1 & Group2 & $p$ \\
\hline Right ventricular Sm (cm/s) & $10,57 \pm 4,18$ & $10,52 \pm 3,68$ & 0,959 \\
\hline Right ventricular Em (cm/s) & $9,64 \pm 3,84$ & $10,79 \pm 4,09$ & 0,275 \\
\hline Right ventricular Am (cm/s) & $12,89 \pm 4,68$ & $13,72 \pm 5,89$ & 0,557 \\
\hline Right ventricular IVRT (ms) & $117,99 \pm 50,89$ & $113,03 \pm 32,82$ & 0,665 \\
\hline Right ventricular IVCT (ms) & $97,61 \pm 49,25$ & $98,21 \pm 31,05$ & 0,959 \\
\hline Right ventricular ET (ms) & $241,26 \pm 55,19$ & $256,93 \pm 49,85$ & 0,275 \\
\hline Right ventricular MPI & $0,94 \pm 0,34$ & $0,88 \pm 0,38$ & 0,501 \\
\hline Left ventricular Sm (cm/s) & $7,89 \pm 3,36$ & $9,17 \pm 2,66$ & 0,121 \\
\hline Left ventricular Em (cm/s) & $7,93 \pm 3,62$ & $9,83 \pm 4,74$ & 0,096 \\
\hline Left ventricular Am (cm/s) & $13,04 \pm 4,42$ & $13,72 \pm 5,93$ & 0,623 \\
\hline Left ventricular IVRT (ms) & $124,25 \pm 32,56$ & $135,75 \pm 33,03$ & 0,195 \\
\hline Left ventricular IVCT (ms) & $113,02 \pm 44,42$ & $127,78 \pm 35,20$ & 0,174 \\
\hline Left ventricular ET (ms) & $238,78 \pm 47,27$ & $234,74 \pm 33,34$ & 0,713 \\
\hline Left ventricular MPI & $1,05 \pm 0,39$ & $1,15 \pm 0,31$ & 0,276 \\
\hline
\end{tabular}

Abbreviations: Sm - systolic peak velocity, Em - early peak velocity, Am atrial peak velocity, IVRT - isovolumetric relaxation time, IVCT - isovolumetric contraction time, ET - ejection time, MPI - myocardial performance index.

the left lateral myocardial performance index was lower in group 1 than in group 2 . This difference was statistically significant $\left(\mathrm{p}=0.050^{*}\right)($ Table 5$)$. No difference in the right lateral myocardial performance index was detected between the two groups $(p=0.617)$ (Table 6$)$. After bypass surgery, the mean postoperative left ventricular myocardial performance index $(0.84 \pm 0.30)$ was significantly lower than the mean preoperative left ventricular myocardial performance index $(1.10 \pm 0.35)$ $(p=0.001)$. However, no difference was observed between the mean preoperative right ventricular myocardial performance index $(0.91 \pm 0.36)$ and the mean postoperative right ventricular myocardial performance index $(0.89 \pm 0.35)(\mathrm{p}=0.783)$.

\section{Discussion}

To our knowledge, our study is the first investigation of the impact of tirofiban use prior to coronary artery bypass on the ventricular performance of patients with left main coronary artery disease. In this study, the left ventricular myocardial performance index was significantly lower in group 1 than in 
Table 5 Postoperative left ventricular systolic and diastolic function measurements

\begin{tabular}{|l|l|l|l|}
\hline & Group1 & Group2 & $p$ \\
\hline Mitral Emax (cm/s) & $79,76 \pm 25,26$ & $73,62 \pm 20,86$ & 0,404 \\
\hline Mitral Amax (cm/s) & $77,47 \pm 29,63$ & $72,66 \pm 20,69$ & 0,560 \\
\hline Mitral E deceleration time (ms) & $255,75 \pm 69,02$ & $234,60 \pm 48,97$ & 0,297 \\
\hline Mitral E/A ratio & $1,10 \pm 0,38$ & $1,09 \pm 0,47$ & 0,939 \\
\hline LVM & $223,56 \pm 44,72$ & $243,43 \pm 80,92$ & 0,314 \\
\hline LVMI & $123,59 \pm 19,14$ & $139,96 \pm 46,59$ & 0,288 \\
\hline left ventricular Sm (cm/s) & $8,92 \pm 3,67$ & $10,12 \pm 2,91$ & 0,182 \\
\hline left ventricular Em (cm/s) & $9,09 \pm 3,82$ & $11,34 \pm 5,08$ & 0,064 \\
\hline left ventricular Am (cm/s) & $11,50 \pm 4,58$ & $11,97 \pm 5,77$ & 0,737 \\
\hline left ventricular E/A ratio & $1,21 \pm 0,51$ & $1,38 \pm 0,62$ & 0,265 \\
\hline left ventricular IVRT (ms) & $96,21 \pm 35,56$ & $117,71 \pm 30,07$ & $0,018^{*}$ \\
\hline left ventricular IVCT (ms) & $90,26 \pm 41,38$ & $107,93 \pm 37,99$ & 0,102 \\
\hline left ventricular ET (ms) & $256,82 \pm 47,45$ & $253,04 \pm 37,74$ & 0,742 \\
\hline left ventricular MPI & $0,76 \pm 0,31$ & $0,92 \pm 0,27$ & $0,050^{*}$ \\
\hline LVEF & $61,46 \pm 7,74$ & $52,87 \pm 11,64$ & $0,003^{*}$ \\
\hline
\end{tabular}

Abbreviations: LVM - left ventricular mass, LVMI - left ventricular mass index $\mathrm{Sm}$ - systolic peak velocity, Em - early peak velocity, Am - atrial peak velocity, IVRT - isovolumetric relaxation time, IVCT - isovolumetric contraction time, ET - ejection time, MPI - myocardial performance index, LVEF - left ventricular ejection fraction.

Table 6

Postoperative right ventricular systolic and diastolic function measurements

\begin{tabular}{|l|l|l|l|}
\hline & Group1 & Group2 & $p$ \\
\hline Right ventricular Sm (cm/s) & $11,46 \pm 4,25$ & $11,62 \pm 3,80$ & 0,879 \\
\hline Right ventricular Em (cm/s) & $10,14 \pm 4,06$ & $11,66 \pm 4,13$ & 0,167 \\
\hline Right ventricular Am (cm/s) & $12,11 \pm 4,66$ & $12,86 \pm 5,59$ & 0,583 \\
\hline Right ventricular Em/Am ratio & $0,87 \pm 0,36$ & $1,03 \pm 0,53$ & 0,179 \\
\hline Right ventricular IVRT (ms) & $116,28 \pm 50,67$ & $111,55 \pm 33,95$ & 0,682 \\
\hline Right ventricular IVCT (ms) & $97,04 \pm 48,88$ & $97,66 \pm 31,09$ & 0,955 \\
\hline Right ventricular ET (ms) & $242,25 \pm 55,57$ & $260,86 \pm 50,64$ & 0,201 \\
\hline Right ventricular MPI & $0,93 \pm 0,34$ & $0,86 \pm 0,37$ & 0,433 \\
\hline
\end{tabular}

Abbreviations: Sm - systolic peak velocity, $\mathrm{Em}$ - early peak velocity, Am: - atrial peakvelocity, IVRT - isovolumetric relaxation time, IVCT — isovolumetric contraction time, ET - ejection time, MPI - myocardial performance index.

group $2\left(\mathrm{p}=0.050^{*}\right)$ and the ejection fraction was higher in group 1 than in group $2(\mathrm{p}=0.003)$. Also, after bypass surgery, the mean postoperative left ventricular myocardial performance index $(0.84 \pm 0.30)$ was significantly lower than the mean preoperative left ventricular myocardial performance index $(1.10 \pm 0.35) \quad(p=0.001)$. This result indicates that tirofiban exerts a protective effect on the performance of the left ventricle.

After cardiopulmonary bypass, the left and right ventricular functions are adversely affected by factors such as myocardial ischemia, reperfusion injury and vasoconstriction induced by hypothermia [6]. Left ventricular diastolic function begins to improve immediately after coronary artery bypass and returns to preoperative levels in the long term. In contrast, right ventricular dysfunction does not completely resolve and is encountered after both on-pump and off-pump surgery [7]. Left ventricular dysfunction and cardiac failure are important independent risk factors for surgical mortality after coronary artery bypass $[8,9]$.

The use of glycoprotein IIb/IIIa inhibitors after coronary interventions is currently common. Glycoprotein IIb/IIIa inhibitors prevent platelet aggregation and thrombus formation by blocking the glycoprotein IIb/IIIa receptors on the surface of platelets that promote aggregation. Among the drugs in this group, tirofiban takes effect rapidly, exerts an antiplatelet effect that disappears shortly after discontinuation, and is highly specific for glycoprotein IIb/IIIa receptors. The efficiency of tirofiban was demonstrated in three large scale studies: Platelet Receptor Inhibition for European Journal of Cardio-thoracic Surgery (PRISM), PRISM-Patients Limited by Unstable Signs and Symptoms (PRISM-PLUS) and Randomized Efficacy Study of Tirofiban for Outcomes and Restenosis (RESTORE) [10-12]. The increased use of coronary stents and glycoprotein IIb/IIIa inhibitors has markedly reduced the incidence of emergent and urgent coronary artery bypass graft surgery for unsuccessful percutaneous coronary intervention [13]. Moreover, a number of studies demonstrated that the use of tirofiban after unsuccessful percutaneous coronary angioplasty does not increase the incidence of bleeding after urgent coronary artery bypass operations [14-15]. However, no previous studies of the impact of tirofiban on myocardial performance after heart surgery are currently available.

Tissue Doppler imaging combined with echocardiography is a practical, reliable and well-defined, non-invasive diagnostic method that has recently been used to investigate left and right ventricular systolic and diastolic function $[4,5]$. Echocardiographic evaluation of the right ventricle is very difficult due to its geometry and its position immediately below the sternum. The myocardial performance index obtained via tissue Doppler imaging is used to evaluate the non-geometrical systolic and diastolic functions. This parameter has been reported to be reliable for evaluating right $[16,17]$ and left [18] ventricular performance. Myocardial performance is not affected by the pulse rate or blood pressure $[19,20]$. High myocardial performance values are associated with adverse cardiac events [21, 22]. In our study, the left ventricular myocardial performance index value was significantly lower in group 1 than in group $2\left(\mathrm{p}=0.050^{*}\right)$.

Microvascular obstruction is present in one-quarter to onethird of patients in whom TIMI 3 has been achieved using mechanical or pharmacological methods [23, 24]. Microvascular obstruction has been reported to cause intracardiac hemorrhage [25] and myocardial rupture [26]. A previous study on the use of abciximab, which is also a glycoprotein IIb/IIIa inhibitor, after acute myocardial infarction demonstrated that this drug is more effective than classical fibro analytical therapy against microvascular obstruction [27].

Clopidogrel is routinely administered to patients with acute coronary artery disease who seek emergency services. This drug has a long half-life; thus, if a coronary artery dis- 
ease, such as left main coronary artery stenosis, is detected in such patients during coronary angiography and a surgical operation is necessary, surgery cannot be performed immediately due to the previous use of clopidogrel. An initial waiting period is necessary after the discontinuation of clopidogrel; in the absence of a waiting period, bleeding and mortality [28] rates increase in the postoperative period. In contrast, an acute coronary syndrome may redevelop if clopidogrel is not administered. As a glycoprotein IIb/IIIa antagonist, tirofiban is a drug that inhibits platelet aggregation. This drug is used increasingly in intensive care units because it can be used up to 4-6 hours before coronary artery bypass surgery.

However, no studies of the impact of this drug on ventricular function in the postoperative period are available. We found that preoperative administration of tirofiban improved postoperative left ventricular performance in

\section{References}

1. Tcheng JE. Clinical challenges of platelet glycoprotein IIb/Illa receptor inhibitor therapy: bleeding, reversal, thrombocytopenia, and retreatment. Am Heart J. 2000;139: S38-S45. 2.Tcheng JE, Harrington RA, Kottke-Marchant K, Kleiman NS, Ellis SG, Kereiakes DJ, et al. Multicenter, randomized, double-blind, placebo-controlled trial of the platelet integrin giycoprotein llb/lla blocker integrelin in elective coronary intervention. Circulation. 1995; 91:2151-7.

3. Batyraliev TA, Fettser DV, Vural A, Pershukov IV, PreobrazhenskiĪ DV, Avşar O, et al. Safety and efficacy of the use of glycoprotein Ilb/lla inhibitors in the invasive treatment of patients with ST-elevation ac ute coronary syndrome. Kardiologiia. 2009;49:4-9 [abstract].

4. Galiuto L, Ignone G, DeMaria AN. Contraction and relaxation velocities of the normal left ventricle using pulsed-wave tissue Doppler echocardiography. Am J Cardiol. 1998;81:609-14

5. Alam M, Wardell J, Andersson E, Samad BA, Nordlander R. Characteristics of mitral and tricuspid annular velocities determined by pulsed wave Doppler tissue imaging in healthy subjects. J Am Soc Echocardiogr. 1999;12:618-28.

6. Wallace A, Lam HW, Nose' PS, Bellows W, Mangano DT. Changes in systolic and diastolic ventricular function with cold cardioplegic arrest in man. The Multicenter Study for Perioperative Ischemia (McSPI) Research Group. J Card Surg. 1994;9 (3 Suppl):497-502.

7. Diller GP, Wasan BS, Kyriacou A, Patel N, Casula RP, Athanasiou T, et al. Effect of coronary artery bypass surgery on myocardial function as assessed by tissue Doppler echocardiography. Eur J Cardiothorac Surg. 2008;34: 995-9.

8. Wang J, Xiao F, Ren J, LiY, Zhang ML. Risk factors for mortality after coronary artery bypass grafting in patients with low left ventricular ejection fraction. Chin Med J (Engl). 2007; 120:317-22.

9. Topkara VK, Cheema FH, Kesavaramanujam S, Mercando ML, Cheema AF, Namerow PB, et al. Coronary artery bypass grafting in patients with low ejection fraction. Circulation. 2005; 112 (9 Suppl): I344-50.

10. PRISM Study Investigators. A comparison of aspirin plus tirofiban with aspirin plus heparin for unstable angina. Platelet receptor inhibition in ischemic syndrome management (PRISM) study investigators. N Engl J Med. 1998;338:1498-505.

11. PRISM-PLUS Study Investigators. Inhibition of the platelet glycoprotein IIb/Illa receptor with tirofiban in unstable angina and non-Q-wave myocardial infarction. Platelet receptor inhibition in ischemic syndrome management in patients limited by unstable signs and symptoms (PRISMPLUS) study investigators. N Engl J Med. 1998;338:1488-97.

12. The RESTORE Investigators. Effects of platelet glycoprotein llb/lla blockade with tirofiban on adverse cardiac events in patients with unstable angina or acute myocardial infarction undergoing coronary angioplasty. Circulation. 1997;96:1445-53.

13. Altmann DB, Racz M, Battleman DS, Bergman G, Spokojny A, Hannan EL et al. Reduction in angioplasty complications after the introduction of coronary stents: results from a consecutive series of 2242 patients. Am Heart J. 1996;132:503-7.

14. De Carlo M, Maselli D, Cortese B, Ciabatti N, Gistri R, Levantino M, et al. Emergency coronary artery bypass grafting in patients with acute myocardial infarction treated with glycoprotein Ilb/Illa receptor inhibitors. Int J Cardiol. 2008;123:229-33 [abstract]. patients with left main coronary artery disease undergoing coronary artery bypass surgery compared to pretreatment with aspirin alone. Therefore, we recommend the preoperative administration of tirofiban as an antithrombotic to patients who are undergoing coronary artery bypass for left main coronary artery disease.

\section{Study Limitations}

This study included a small registry of patients and has all of the limitations of a non-randomized trial. We found that tirofiban exerts a positive effect on left ventricular performance. However, the mechanism that underlies this effect is not fully known. The effectiveness of this drug might be linked to its ability to reduce microvascular obstructions. Additional large-scale studies that use more effective methods to evaluate microvascular obstruction are needed.

15. Cheng DK, Jackevicius CA, Seidelin P, Feindel C, Rouleau JL. Safety of glycoprotein Ilb/ Illa inhibitors in urgent or emergency coronary artery bypass graft surgery. Can J Cardiol. 2004;20:223-8

16. Tei C, Dujardin KS, Hodge DO, Bailey KR, McGoon MD, Tajik AJ, et al. Doppler echocardiographic index for assessment of global right ventricular function. J Am Soc Echocardiogr. 1996;9:838-47.

17. Eidem BW, O'Leary PW, Tei C, Seward JB. Usefulness of the myocardial performance index for assessing right ventricular function in congenital heart disease. Am J Cardiol. 2000; 86:654-8.

18. Poelaert J, Heerman J, Schüpfer G, Moerman A, Reyntjens K, Roosens C. Estimation of myocardial performance in CABG patients. Acta Anaesthesiol Scand. 2004;48:973-9.

19. Tei C, Ling LH, Hodge DO, Bailey KR, Oh JK, Rodeheffer RJ et al. New index of combined systolic and diastolic myocardial performance: A simple and reproducible measure of cardiac function-a study in normals and dilated cardiomyopathy. J Cardiol. 1995;26:357-66.

20. Parthenakis FI, Kanakaraki MK, Kanoupakis EM, Skalidis El, Diakakis GF, Filippou OK, et al. Value of Doppler index combining systolic and diastolic myocardial performance in predicting cardiopulmonary exercise capacity in patients with congestive heart failure: Effect of dobutamine. Chest. 2002;121:1935-41.

21. Poulsen SH, Jensen SE, Tei C, Seward JB, Egstrup K. Value of the Doppler index of myocardial performance in the early phase of acute myocardial infarction. $J$ Am Soc Echocardiogr. 2000; 13:723-30.

22. Bruch C, Schmermund A, Dagres N, Katz M, Bartel T, Erbel R. Severe Aortic valve stenosis with preserved and reduced systolic left ventricular function: Diagnostic usefulness of the tei index. J Am Soc Echocardiogr. 2002; 15:869-76.

23. Ragosta M, Camarano GP, Kaul S, Powers ER, Sarembock IJ, Gimple LW. Microvascular integrity indicates myocellular viability in patients with recent myocardial infarction: New insights using myocardial contrast echocardiography. Circulation. 1994; 89: 2562-9.

24. Ito H, Okamura A, Iwakura K, Masuyama T, Hori M, Takiuchi S, et al. Myocardial perfusion patterns related to thrombolysis in myocardial infarction perfusion grades after coronary angioplasty in patients with acute anterior wall myocardial infarction. Circulation. 1996; 93: 1993-9.

25. Asanuma T, Tanabe K, Ochiai K, Yoshitomi H, Nakamura K, Murakami Y, et al. Relationship between progressive microvascular damage and intramyocardial hemorrhage in patients with reperfused anterior myocardial infarction: Myocardial contrast echocardiographic study. Circulation. 1997; 96: 448-53.

26. Zoni A, Arisi A, Corradi D, Ardissino D. Images in cardiovascular medicine. Magnetic resonance imaging of impending left ventricular rupture after acute myocardial infarction. Circulation. 2003; 108: 498-9.

27. Zoni A, Knoll P, Gherli T. Microvascular obstruction after successful fibrinolytic therapy in acute myocardial infarction. Comparison of reteplase vs reteplase+abciximab: A cardiovascular magnetic resonance study. Heart International. 2006; 2: 54-65.

28. Varenhorst C, Alström U, Scirica BM, Hogue CW, Åsenblad N, Storey RF, et al. Factors contributing to the lower mortality with ticagrelor compared with clopidogrel in patients undergoing coronary artery bypass surgery. J Am Coll Cardiol. 2012;60:1623-30. 